\title{
Understanding curriculum design in the perceptions and practices of classroom music teachers in the lower secondary school in England
}

Curriculum design is a domain which infrequently forms a discrete element of initial teacher training, or continuing professional development for music teachers in English secondary schools. Classroom music teachers, teaching Key Stage 3 learners ( $11-14$ year olds), are, however, required to design their own curriculum. Teachers are accountable to school leaders for curricula they implement, and the outcomes from their selected approaches. This article will discuss classroom music curriculum practices and their significance in music education. The research project was conducted with music teachers from schools in the East and West Midlands of England, utilising questionnaires and semi-structured interviews. Research findings are conceptualised in a model of music curriculum activity. The research thereby facilitates discussion of unacknowledged complexities and tacit teacher planning practices in music curriculum design.

Keywords: curriculum conceptualisation, curriculum design, curriculum activity model, music pedagogies

\section{Introduction}

Characteristics of musical learning, such as formal and informal modes (Green, 2001), intentionality (Philpott, 2007), and transformation (Swanwick, 1999) have received considerable attention in music education literature. However, understanding processes with which secondary music teachers engage whilst designing their Key Stage 3 (KS3) curricula for $11-14$ year olds remains a developing field. Multiple perspectives of classroom music education, arising from individual musical philosophies, have led to diversity of curriculum realisations and disparate planning practices. This may be, in part, due to a relative lack of curricula guidance for music in policy formulations.

Since its adoption as a school curriculum subject with the introduction of compulsory schooling in 1880 (HMSO, 1880; Hallam \& Creech, 2010) music has been subject to a diverse range of teacher practices and interpretations of official guidance. However, a significant indication of the importance of these teacher choices was highlighted in Enquiry 1 (Schools Council, 1968), where school leavers indicated their dissatisfaction with music as a curriculum subject. This led to policy movements to make music "relevant to pupils' lives" (HMSO, 1972), resulting in the Schools 
Council project led by Paynter during the 1970s (Paynter, 1982). Ultimately, music was adopted as a National Curriculum subject in 1992 (DfE, 1991), which secured its inclusion in the educational experience of young people, although the nature of this experience continued to demonstrate variance (Plummeridge, 2002).

The National Curriculum for Music itself proved to be similarly varied, as its form continued to develop. The subject content of the 2013 version of the National Curriculum for Music (DfE, 2013) consists of 209 words for three years of Key Stage 3 (KS3) Music in secondary schools in England. It is from these that teachers design their musical origins for teaching and learning. This compares with 2,270 words in the previous revision of the KS3 Music curriculum for England in 2007 (QCA, 2007); a 39 page booklet of the curriculum issued in 1999 (QCA, 1999); and a 33 page folder of curriculum orders alongside a 42 page book of Non-Statutory Guidance published together in 1992 (NCC, 1992) (Anderson, 2019, p. 18 - 19). The proposed model music curriculum (DfE, 2019), which has now been indefinitely delayed, was also proposed as a non-statutory document, existing solely for pedagogical guidance. Proposed by Nick Gibb, the minister of state for school standards, this framework aspired to provide schools with a "sequenced and structured template for Key Stages 1, 2, and 3" (DfE, 2019, p.1) in music. The development of such a representation of musical learning demonstrated the desire to formalise musical pedagogies, but the inability to realise this aim demonstrates the complexity of classroom music, with its multi-modal interactions.

There is, therefore, a lack of consensus in approaches for developing music curriculum structures of musical learning in policy discourse. It is left to classroom music teachers to construct their curriculum from the relatively brief guidance. A varied mixture of taught content and practice in the English lower secondary school classroom therefore exists, which is dependent on conceptualisation and practice of 
music as interpreted by the generalist music teacher. One KS3 study (Fautley, 2015) based on data taken from 84 London schools, found that 76 discrete topics were used to facilitate musical learning, of which 41 topics were unique, existing in only one school. This informal custom and practice approach can be viewed as an example of what Bruner (1996, p.44) referred to as "folk pedagogy". In the case of KS3 Music, this is a way of organising and delivering music curricula materials and demonstrates lack of commonality with other practitioners. Music teaching thus demonstrates an extreme variety of practice, facilitating a rich musical learning experience for young people. However, this range of musical pedagogies can make it complex to unpick conceptual models which lie behind choices teachers make in their curriculum design.

\section{Musical pedagogies and curriculum design}

Practices in musical pedagogy since the Schools Council Secondary Music Project (Paynter, 1982) remain diverse. There continues to be a lack of musical learning models on which there is consensus. Swanwick's CLASP model (1979) delineated five specific musical characteristics for classroom learning: composition, literature studies, audition, skill acquisition and performance (CLASP). The emphasis placed on the CLASP elements, particularly composing, skill acquisition, and performing, did not feature in a singing and musical appreciation pedagogy that formed dominant practices in post-war music education.

Attempts have consistently been made to establish links between formal and informal learning, although there similarly remains a lack of agreement in this area. Sloboda (1985) made an early attempt to link the two, regarding formal and informal learning as a linear sequential development. His approach placed emphasis on musical learning as intuitive and occurring without conscious effort. Swanwick and Tillman's (1986) spiral presents another synthesis. Regarding developmental theory as not 
only progressive layers, but experiential, Swanwick and Tillman considered musical development as a movement through materials, expression, form and value, which develops from starting points of play and imitation through to aesthetic and analysis. Swanwick and Tillman's thinking on musical discourse and their attempts to produce a developmental theory of musical learning, laid the foundation for the emergence of an approach to understanding musical progression in classroom music in general, but especially in composing. Green (2001) later sought to define the differences between formal, informal and non-formal learning, the areas in which music-making and musical learning occur, within "vernacular music practices" (2001, p. 17).

Within these varied modalities of music curriculum pedagogy, the sub-set of curriculum design has, however, received little attention. Music curriculum design, in this article, is defined as the development of programmes of study across each year group in the English high school, through which young people experience, engage, and develop their musicality through musical encounters, facilitated through teacher enacted musical pedagogies. The KS3 music curriculum in England tends towards topic-based learning, where a musical style, genre or tradition is explored, often in units of half a term. As part of teacher training, music specialists receive limited opportunity to develop their thinking in curriculum design or articulate rationales for topic order and relationships between them to facilitate progress. As school music departments tend to be staffed by one or two individuals (Daubney \& Mackrill, 2017), this often means that teachers lead in the design of music curriculum relatively early in their careers. There is limited UK-focused literature on which they can draw to facilitate this task.

\section{Curriculum design and policy}

Guidance on effective music teaching from the Office for Standards in Education (Ofsted) suggests that the main direction of individual lessons needs to be clear 
(Ofsted, 2009, p. 31). The 2013 report Music in Schools: what hubs must do (Ofsted, 2013) frequently discusses how schools should work with their local music hubs to develop musical curricula. (A hub is a development from Local Education Authority (LEA) music service provision, in which music partners work together to create a music education offer for young people in a geographical region (DfE, 2011). Operational from 2012, there are presently 120 hubs, each receiving a funding grant from the $£ 79$ million, for $2020-21$, which the Department for Education administers through Arts Council England.) These Ofsted reports do not identify the nature of musical learning or attempt to define curriculum. In the National Strategy for Music, published by the Department for Education and Skills (DfES) in 2006, there is an emphasis on identifying how students develop understanding and the part that music-making plays in this (2006 p. 4). Making links with prior learning is a part of this conceptualisation that is also emphasised (DfES, 2006, p. 3). However, at the time this research was conducted $(2012-2013)$, there was no suggestion for how music curriculum aims, planning and outcomes might align.

Since this research was conducted, the most notable development has been the increasing concentration by Ofsted on curriculum, which it has sought to define and rationalise. Its three pronged conceptualisation of curriculum as intent, implementation and impact (Ofsted, 2019) has resulted in curriculum becoming processed through a reductionist paradigm, within which teachers seek to reinterpret their former conceptualisations of 'curriculum' as an educational term. This is evidenced in continuing professional development for teachers, where curriculum comes to be understood as the quality of education (Brown, 2020), and is also evident in the emergence of new terminologies which describe scrutiny of school subject practices. For example, Ofsted inspections now feature "deep dives" (Spielman, 2020) as a way of "identifying systemic causes for issues/strengths" (Rudland, 2020). A deep dive considers a selection of subjects in the context of 
whole-school data analysis and an inspection visit. This is in place of visits formerly described as subject-survey visits, also known as subject-specific inspections (Ofsted, 2013b).

Despite the developments in policy discourse, there remains some disparity between curriculum constructs as defined in the inspection literature, and curriculum as practised by music teachers in schools. The notion of a considered programme of study for music teaching topics across the academic year is underdeveloped in music education research. This is the wider realisation of what Philpott terms as ordering sounds and musical meaning before "written notations and technical analysis" (Philpott, 2007, p.166). It is this landscape of musical pedagogy and its multi-voiced modality, as realised in variant teacher practice, which highlights the multiple research domains that this research project has sought to develop.

\section{Methodology and ethics}

In exploring classrooms as social settings, in which teacher interaction is realised through curriculum design, the research project discussed in this article adopted a mixed methods approach (Newby, 2010), which incorporated analysis of an on-line survey and follow-up semi-structured interviews. This enabled contextual subtlety to emerge, especially within classroom settings, which are complex social environments (Kinsella, 2017).

The on-line questionnaire was analysed quantitatively where there were closed responses, and qualitatively where there were opportunities for open responses, each structure determining the choice of methodological tool. Follow-up semistructured interviews were analysed using modified grounded theory (Glaser \& Strauss, 1967), which allowed preliminary themes to emerge. 
The research questionnaire received engagement from 64 respondents and was completed using the Bristol On-Line Surveys (BOS) software, which enabled electronic capture and interrogation of data. It consisted of a variety of closed questions to permit scope, and open questions to facilitate sophistication of response. Follow-up semi-structured interviews were conducted with 9 teachers, each a different school. The analysis of questionnaires and interviews presented here is limited to teacher perceptions of curriculum design activity, the theme of this article. The research study was conducted between $18^{\text {th }}$ December 2012 and $9^{\text {th }}$ July 2013.

On-line surveys were completed by music teachers across England, and semistructured interviews, and documentary analysis data collection was located in schools in the West and East Midlands. Research participant music teachers were of different genders, ages, and career stage. Teaching background demonstrated variance across the research sample and included those who had worked in fields of popular music and music technology, and others who were classically trained; and included conventional routes into music teaching (e.g. Music A-level and Music degree) to less traditional ones (e.g. no Music degree or primary teacher training before transferring to the secondary school sector at a later date).

The research was guided by principles of informed consent (Miles \& Huberman, 1984; Yin, 2009), and research participants were assured of anonymity (Miles \& Huberman, 1984). Arrangements for fieldwork were consistently formed in an ethically congruent manner. Schools were selected in order to ensure maximum variation sampling (Cohen, Manion \& Morrison, 2007) in terms of their size, Pupil Premium profile, Special Educational Needs and ethnic origins. There was a wide range of school participants in all these areas, ensuring that no one type of school context was privileged over another. 


\section{Findings}

\section{How music teachers conceptualise music curriculum}

Before curriculum design can occur, music teachers have first to consider their individual perspectives on how to conceptualise curriculum. Such conceptualisations include, among other things: the characteristics of a musical curriculum, how skills, knowledge and understanding operate and their points of integration or overlap, and how musical activity is positioned to enable musical learning. The research questionnaire for this project was designed to access teacher participant responses to both curriculum conceptualisation and curriculum design. In the domain of curriculum conceptualisation, when participants were asked if they had received any "formal training" in curriculum design (Q1), the majority affirmed that this was the case $(68.8 \%)$, and for most this was a part of initial teacher training $(59.1 \%$ Q1a), suggesting that unless within the first five years of their careers, this may have been experienced at a distance to practice. Conceptualisation of curriculum was also primarily focused on making music as a gateway to musical learning by the teacher participants. This can be seen in the response to question 2, which explored musical rationales for curriculum planning, rather than musical activity per se, in which $68.8 \%$ of participants chose music-making as the central feature of curriculum design:

\begin{tabular}{|r|l|l|c|}
\hline 2. Which of these statements most closely matches your own thinking? \\
\hline $\begin{array}{r}\text { Musical learning is } \\
\text { content driven: }\end{array}$ & $\square$ & $6.2 \%$ & 4 \\
\hline $\begin{array}{r}\text { Musical learning is } \\
\text { determined by } \\
\text { resources: }\end{array}$ & $\square$ & $4.7 \%$ & 3 \\
\hline $\begin{array}{r}\text { Musical learning is about } \\
\text { making music: }\end{array}$ & & $68.8 \%$ & 44 \\
\hline $\begin{array}{r}\text { Musical learning is } \\
\text { creativity centred: }\end{array}$ & & $20.3 \%$ & 13 \\
\hline
\end{tabular}

Figure 1: Questionnaire findings for substances of musical learning 
Music curricula, were therefore, not conceptualised as a body of deliverable knowledge, but as a process of music-making through which learning occurred. This was borne out in other aspects of the research, such as teachers' repeated comments during interviews about 'practical' music-making as essential. This distinction between curriculum as a body of knowledge, and curriculum as a constructivist paradigm, led to teacher participants describing implicit, rather than explicit links between their curriculum conceptualisation and school definitions. In other words, the music curriculum which they had designed, and curriculum as discussed and enacted by their school leaders were not connected. Teacher participants also identified links between music and their whole school curriculum in professional expectations, such as assessment and policies.

Whilst schools did exhibit unified approaches in timetabling (the number of lessons per week in each subject, and the number of hours per year expressed in school policies), there was a different approach to KS3 curricula, which was conceptualised and designed by music subject leaders without explicit guidance.

This is linked to the status with which participants associated music as a subject within their school communities. This was frequently perceived as low-status by research participants:

Not as important as English, Maths and Science.

Does not have priority over core subjects, needs development with computers and accommodation.

At the bottom of the ladder. 
The professional dialogue between Senior Leadership Teams and Subject Leaders for music therefore appears, to some extent, to frame contexts for curriculum design for KS3 classroom music. Where there is a diminished discourse between levels of leadership considering curriculum design at subject level, this is realised in procedural rather than pedagogical engagement. Interview responses therefore tended to be around elements such as perceived GCSE take-up, rather than subject content and its organisation.

The perceived low-status of music on the curriculum has been a long-standing issue in music education. Plummeridge (2001) suggested that the place of music in the curriculum has never been entirely secure and discussions seeking to articulate its importance draw on a wide-range of justifications. These include its centrality as a cultural artifact (Welch, 2005) and equality of access embodying tensions between social justice and policy-making (Bate, 2020). Such justifications are made against an educational backdrop in which subjects are valorised into core subjects (English, Maths and Science) and foundation subjects (everything else). This perpetuates an educational landscape in which arts education is of secondary importance. The perspective of music in curriculum as low-status has been further consolidated through its exclusion from the English Baccalaureate (EBacc) in England. The EBacc is a suite of approved subjects whose GCSE outcomes form part of measures used to evaluate individual school performance, and has been a significant contributory factor in maintaining music's peripheral nature as a school subject. The bearing of the EBacc on music education in England has "significantly negatively impacted on music education in schools" (APPGME, 2019, p. 3) and has been attributed to declining numbers of young people taking GCSEs in arts subjects since its introduction (Bath, Daubney, Mackrill \& Spruce, 2020). Music teachers' perceptions of music in the curriculum is thus also evidenced in music research literature. Therefore conceptualisations of the arts as subjects of lower-status and 
value is perpetually emphasised through structures which form the bedrock of whole school performance measures.

\section{How teachers enact curriculum design}

In the domain of curriculum design, (the development of programmes of study featuring enacted musical pedagogies), when teacher participants were asked (Q5) if their music curriculum was topic based, the majority of participants answered that it was $(85.9 \%)$ :

\section{Section 2: Putting a curriculum together}

5. Music teaching in the classroom can follow topics. A topic is defined as a genre, musical form or context. (E.g. minimalism, Indian classical music, ternary form). Is your music curriculum topic-based?

\begin{tabular}{|r|l|c|c|}
\hline Yes: & $85.9 \%$ & 55 \\
\hline No: & & $8 \%$ & $14.1 \%$ \\
\hline & 9 & 14 \\
\hline
\end{tabular}

5.a. If you do not teach in topics, how would you describe your approach to designing a music curriculum?

- There are too many responses to display on this page and so all the responses to this question are available on a separate page.

Figure 2 Questionnaire findings on topic-based learning

Of the $14.1 \%$ who responded that their curriculum did not consist of topic-based learning, a free response question (5a) then followed. The majority of these responses $(66 \%)$ evidenced that participants taught in topics within the research definition, but replacing "genre" for "topic". For most participants $(65.6 \%)$ these topics subsisted of units of work lasting half a term. Where there was variation, a range of rationales were identified among the participant responses. These included comments such as: "It is easier to organise" (3\%); "school assessment data deadlines" impacting available class time (13\%); and contextual factors, such as school structures (20\%), which included school timetabling formulations and wholeschool assessment policies. 
Blues emerged as the most frequently taught topic among the questionnaire participants, with sonata form as the least frequently occurring. There was no one style, genre or tradition that took precedence in the most frequently occurring topics. The most frequently occurring topics overall were: Blues (85.7\%); Music for Film and TV (82.9\%) and Musical Elements (also known as "the inter-related dimensions of music" (DfE, 2013, p. 2)) (82.8\%). There is, therefore, tacit teacher consensus of what should be covered in a KS3 Music curriculum, and a consilience of diverse musical palettes, from which Key Stage 3 music teachers in the research mixed and created their curricula. However, the profile for topics taught as part of teachers' Music Key Stage 3 curriculum, varied considerably between years 7, 8 and 9 . There are differences in two domains, where there was varying practice between curriculum design for year 7 , and with years 8 and 9 . Years 8 and 9 were either distinct from each other, or in some instances exhibited closer enacted proximity. For example, within questionnaire findings, year 7 almost always contained a topic on musical elements (82.8\%), whereas year 8 and 9 never did. (The $17.2 \%$ difference here is accounted for by teacher participants who stated that they did not teach Musical Elements at all). The Orchestra was similarly almost entirely delivered to year $7(62.5 \%)$ with $6.2 \%$ of teacher participants including this as a topic in their curriculum for year 8 and $3.1 \%$ including it as a topic for year 9 . African drumming was also primarily treated as a year 7 topic, where $43.8 \%$ of teacher participants included it in their curriculum at this stage, compared to $12.5 \%$ in year 8 and $7.8 \%$ in year 9.

Years 8 and 9 showed more similarity of practice in topics of Song, and Blues, but there remained a significant difference between these upper years of Key Stage 3 and the first year, in Year 7. 32 bar Song Form appeared in $14.1 \%$ of year 8 curricula and $26.6 \%$ of year 9 curricula, but did not appear in Year 7 . Similarly, the Blues appeared in $54.7 \%$ of curricula for Year 8 and $25 \%$ of curricula for Year 9 , 
appearing in $9.4 \%$ of Year 7 curricula. The lowest proportion of teachers of any topic from within the research sample, was those who did not teach Blues at all: $10.9 \%$. Jazz and Minimalism were most popular in Year 9, appearing significantly less in other year groups (see figure 3).

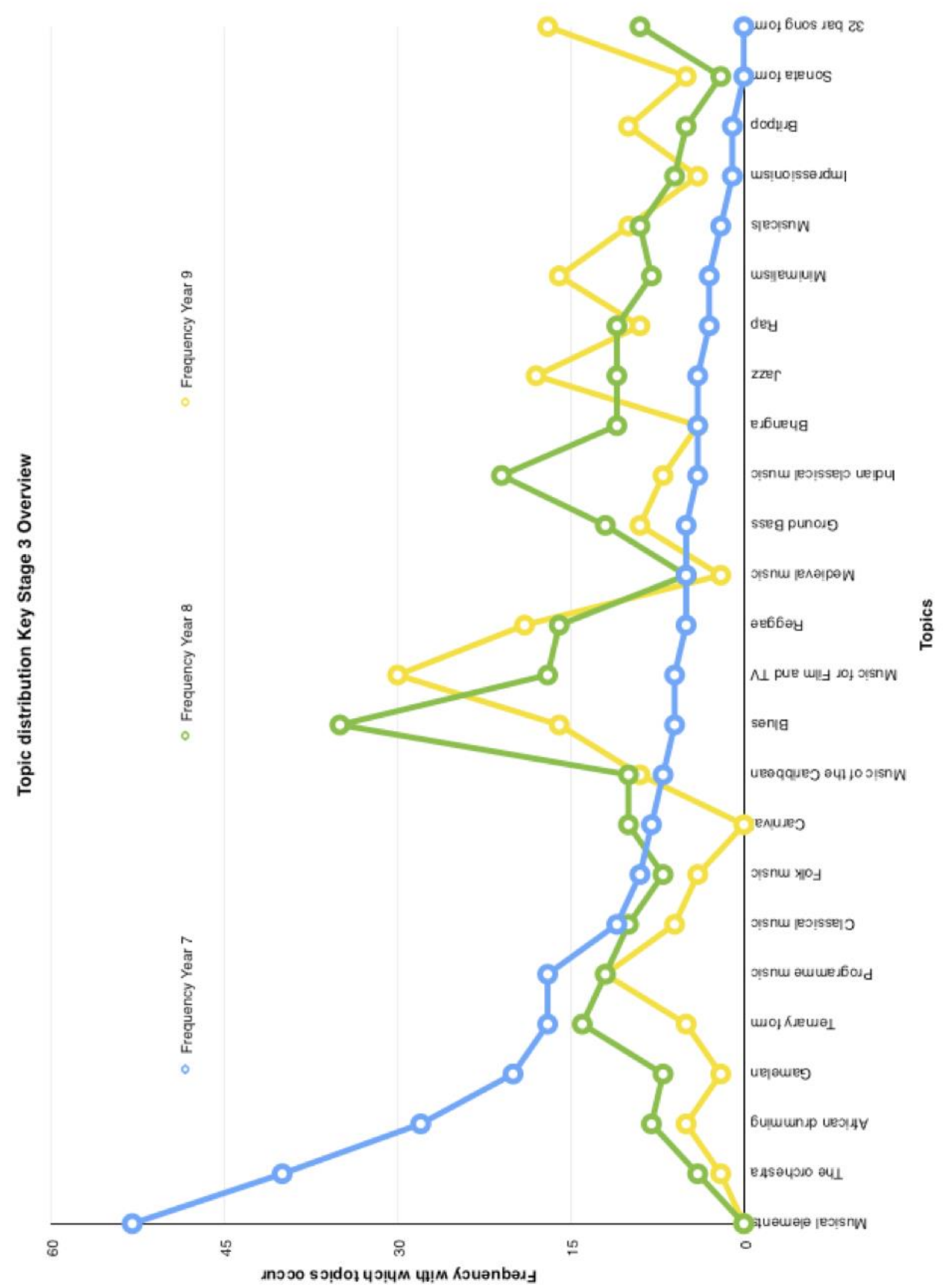

Figure 3: Questionnaire findings - comparative analysis of topics in KS3 
Similarities of teacher participant approaches to planning curricula were evident between years 8 and 9. Examples of this included Rap (17.2\% for Year 8 and $14.1 \%$ for Year 9 ) and Impressionism (9.4\% for year 8 and $6.2 \%$ for year 9$)$. However, the closest similarities were Programme Music (18.8\% for both years 8 and 9); Bhangra (6.2\% for both years 7 and 9); and Medieval Music (7.8\% for both years 7 and 8 ), which evidenced different levels of similarity between school years. There was some clustering around Classical Music for all years (17.2\% for Year 7, 15.6\% for Year 8 and $9.4 \%$ for Year 9), however, as this topic may subsume a wide variety of musical contexts, this was an unremarkable congruence.

Responses from teacher participants to the final question of semi-structured interviews suggest that although teachers wish to retain autonomy in the activity of curriculum design, they are uncertain of spaces their practice occupies, and whether it is representative. For some participants, interviews offered opportunities to think and review this domain for the first time, and this was a reflective moment they welcomed. It was in this interview process, almost at its conclusion, that some of the most open comments were made in relation to music curriculum design:

Yeah, I think, this is the first time that I've ever been asked directly by somebody who's an expert about my musical decisions in my curriculum building really. This is first time somebody's sat down and said what do you do and why. (School D)

I never really thought about it until we spoke today, in terms of the in depth way which we've spoken about it. I think actually when you talk to other teachers about this, the words "happy accident" might actually be a big part of people's vocabulary. (School B)

I've got the way that I do it, but I do find it difficult to know whether that's the right way. I think maybe there is no right way. I don't know, but it is difficult to know whether you are on the right track. It's difficult to know whether what you're doing is correct because it is so open. (School H)

As I said right at the start, I choose to do... to interpret the curriculum in a way which suits me, and I think it suits my community of children, and I would argue that that's how we should do it. I don't think there should be some top down this is how we do it and we must do it in this way, 
because there's so many debates and arguments about how to teach music that there is no one answer. (School I)

I think there's not necessarily a right way to do it. And I think because a lot of my friends are music teachers and we all do it very differently, and I think it's quite a personal thing as well. And I do worry sometimes that I do too much popular music and we don't do enough classical. In another school I might do more of that. (School A)

The planning of lessons and schemes of work within which lessons exist is a frequent and recurring feature of teacher practice. However, teacher decisions around which topics to include is an area in which there is a vacuum of consensus, and in which conflicting discourses of pedagogical practice exist. Conflicts between both professional profile and personal identity, and how this then manifests into realised educational personae for music are therefore evident.

Music teachers continue to conceptualise their curriculum as topics. In a recent survey conducted by Birmingham City University (Fautley, Kinsella \& Whittaker, 2018) $80 \%$ of participants stated that they taught in topics. Of the 38 topics included in survey returns, Blues was the most popular topic, African drumming was fifth and Film music sixth in terms of popularity. In a more recent example, The Oak National Academy (ONA), founded in April 2020 as a response to the suspension of face-toface schooling learning following the Coronavirus pandemic, offers on-line video lessons and resources for teachers in an English context. Initially funded by the Department for Education (DfE), ONA presents a formalised conception of music education that asserts that young people should be "inducted into the powerful cultural knowledge associated with music" (ONA, 2020, p. 2). Such a classification of classroom music adopts a paradigm aligned with behaviourism concerned with the maintenance of the hegemonic status-quo. Despite this perspective on musical learning, ONA includes congruent topics to those listed in the findings section of this article. These include The Blues (in year 8), Film music (in year 9) and West African music (year 8). Therefore although the research discussed in this paper was 
conducted during $2012-2013$, it continues to be relevant to music curriculum design today.

\section{A model of music curriculum activity}

In aspiring to uncover what influences conceptualisations of curriculum, and how this leads to curriculum design in music education, it became clear that practice varied widely. There was no consensus amongst music teachers in how to recognise or realise formulations of the Key Stage 3 music curriculum. As topics which teachers include vary so widely, then rationales for curriculum design can be expected to be similarly broad in their influences and realisation.

Curriculum activity is determined by the priority given to what music teachers described as "practical," which could also be described as music-making or musiccreating processes. Such a focus on musical activity, is a well-established principle in the literature of music education (Paynter, 1992; Swanwick, 1999; Philpott, 2007; Finney, 2017). However, participant music teachers in the research posited that it was musical activity that motivated the curriculum, rather than the curriculum motivating musical activity. This is a significant difference, where music-making is coded as a discourse to ascribe it value, in place of regarding musicking (Small, 1998) as intrinsic to musical dialogue. The evaluation of such curriculum activity is determined by music teachers in the extent to which classroom learners engage with music-making, as framed by pedagogies in operation. If teachers perceive that learners consider the musical activity to be "fun", notions of successful musical learning were reinforced. If learners are not engaged in the topic, then questionnaire findings indicated that more time was allocated to the topic with additional teacher input, in order to enable what teachers considered to be a more successful outcome, although the parameters of how they evaluated this is not clear from research data. Learners therefore have a significant influence over music curriculum as it is 
implemented in their schools. Their engagement, informal remarks and rate of progress in curriculum activity will therefore determine the formation of the curriculum they themselves follow.

There is thus a dual perspective of music teacher and learner, and at significant moments these interact. However, these musical learning experiences are understood differently by both teachers and learners. The model below seeks to clarify these structures:

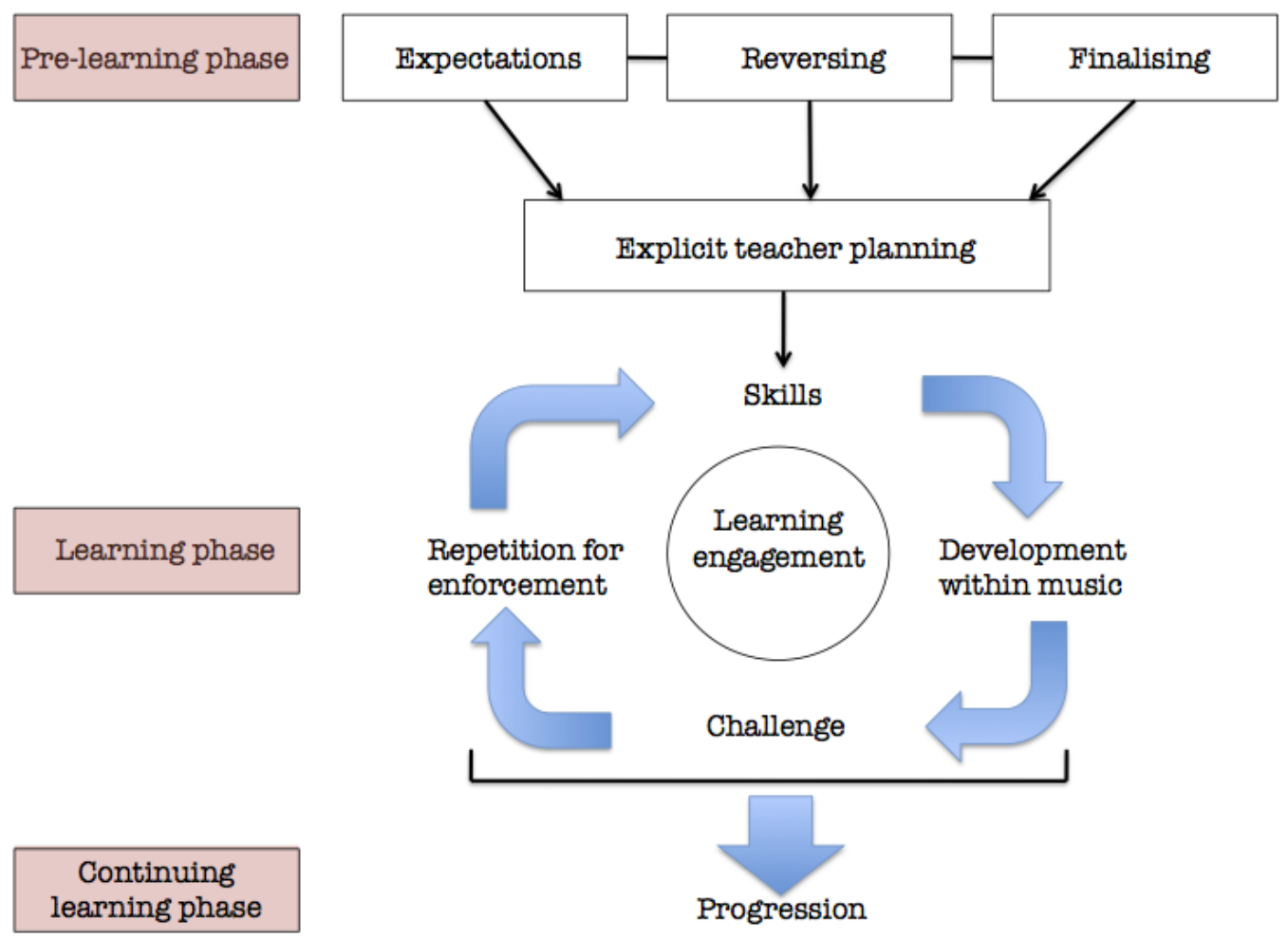

Figure 4: Model of curriculum activity in teacher and learner perspectives

The perspective of the learner in this model of curriculum activity, is that of creating (for example composition episodes), which is facilitated by the music teacher in a process of development. The music teacher perspective exhibits a shared perception of facilitating, and this is part of a cycle of curriculum activity that includes: 
techniquing (developing instrumental facility), progressing (shaping outcomes for progress), projecting (evaluating perceptions of effective student engagement in music), selecting (decision-making about resources and learning pathways) and sequencing (ordering musical topics) before the cycle returns to facilitation.

As part of the model of curriculum activity, actions of facilitating, creating, techniquing, progressing, projecting, selecting and sequencing are described in their differing modes of operation. Pre-active phases consist of projecting, selecting and sequencing, and these are processes that occurred in curriculum design before teachers met their classes. These phases were perceived by teachers as planning, which in operation included multi-faceted actions. Action phases consisted of techniquing and progressing, in which teacher participants realised curriculum activity in pre-determined sequences of musical engagement (e.g. learning finger placement on a keyboard and developing this into broken chords). These actions were not dependent on learner response for their formation, apart from initial and ongoing assessments of progress. Contrastingly, reactive phases within this model were those of facilitating and creating. These required interactive musical dialogue between learner and teacher without which they could not operate. To enable musical feedback, for instance, the teacher was required to access musical material as presented by the learner. Recognising fields of learner and teacher operation and interaction as distinct is therefore significant in understanding how curriculum is actualised in music classrooms: more than one curriculum model is in simultaneous existence, or in-play during classroom musical learning interactions.

\section{Conclusion}

The themes emerging from this study indicate the complex metamorphic nature of music curriculum as practised and realised in classroom settings. Music curricula as observed from within this context exist in a state of flux, due to their multiplicitous 
interactions. The semantics of music realised in curricula formations is problematic to represent, due to simultaneous operation of modes of musical knowing, but its multi-dynamic structure is evident, and care is therefore needed in how a discussion of music curricula is framed. Hidden complexities are barely submerged, and tacit assumptions that music teachers will confidently engage with curriculum design, and conceptual transformations in unacknowledged interactions, indicates the scale of demands that generating considered pedagogical practices involves.

Notwithstanding these demands, such a process is one with which music teachers engage daily. Such intense and demanding interactions are largely unacknowledged, and there is a lack of specified time allocated by school leaders or policymakers for teacher development in this domain. It is therefore significant how effectively music teachers consider their practice within the intensely personal process of consistently aspiring to design rich musical curricula for the musical development of young people. Music curriculum design is therefore a critical fulcrum around which classroom music education operates and merits greater consideration and discussion in the literature of the field. Such a developmental discourse is essential in future theoretical developments, to support musical learning and facilitate critical engagements between young people and their teachers, thus enabling musical learning in a classroom context.

\section{References}

All-Party Parliamentary Group for Music Education (APPGME). (2019). Music education: state of the nation. London, UK: All-Party Parliamentary Group for Music Education, University of Sussex, Incorporated Society of Musicians.

Anderson, A. (2019). Happy accidents? Music teacher perceptions of curriculum design at Key Stage 3 in the English secondary school. Unpublished thesis: Birmingham City University.

Bate, E. (2020). Justifying music in the national curriculum: The habit concept and the question of social justice and academic rigour. British Journal of Music Education, 37(1), 3-15. doi: 10.1017/S0265051718000098 
Bath, N., Daubney, A., Mackrill, D., \& Spruce, G. (2020). The declining place of music education in schools in England. Children \& Society. 20 (0), 1 - 15 doi: $\underline{10.1111 / \text { chso. } 12386}$

Brown, L. (2020). Leadership in primary music and responding to the new Ofsted inspection framework. Presentation at Primary and Secondary Music Education Conference, 13/2/20.

Bruner, J.S. (1996). The Culture of Education. Cambridge MA: Harvard University Press.

Cohen, L., Manion, L., \& Morrison, K. (2007). Research Methods in Education, $9^{\text {th }}$ edition. Abingdon: Routledge.

Daubney, A. \& Mackrill, D. (2017). Changes in Secondary Music Curriculum over Time 2012 - 2016. Falmer Brighton: University of Sussex.

Department of Education and Science (1991). Music for ages 5 to 14: Proposals of the Secretary of State for Education and Science and the Secretary of State for Wales. London: HMSO

Department for Education and Skills (2006). Secondary National Strategy for School Improvement. Foundation Subjects: KS3 Music. London: Crown Copyright.

Department for Education (2011). The Importance of Music: A National Plan for Music Education. London: Crown Copyright.

Department for Education (2013). Music Programmes of Study: Key Stage 3. London: Crown Copyright.

Department for Education (2019). Government backs young musicians. Retrieved from: https://www.gov.uk/government/news/government-backs-young-musicians Accessed on: 10/4/19.

Fautley, M. (2015). Teach Through Music. London: Trinity Laban Conservatoire of Music and Dance.

Fautley, M. Kinsella, V., \& Whittaker, A. (2018). Secondary School Music Teachers Survey 2018. Birmingham: Faculty of Health, Education and Life Sciences, Birmingham City University.

Finney, J. (2017). Music curriculum, pedagogy, assessment and the order of things. Blog retrieved from: https://jifin107.wordpress.com. Accessed on: 8/6/19.

Glaser, B. \& Strauss, A. (1967). The Discovery of Grounded Theory. Chicago: Aldine.

Green, L. (2001). How Popular Musicians Learn. Aldershot: Ashgate.

Kinsella, V. (2017). The Use of Activity Theory as a Methodology for Developing Creativity within the Art and Design Classroom. The International Journal of Art \& Design Education, 10 (1111), pp. 1 - 14.

Hallam, S. \& Creech, A. (2010). Contextualising music education in the UK. 
Music Education in the 21st Century in the United Kingdom (Eds) Hallam, S. \& Creech, A.

Her Majesty's Stationery Office (HMSO) (1880). Elementary Education Act.

Her Majesty's Stationery Office (HMSO) (1972). Music and Integrated Studies in the Secondary School: A bulletin prepared by a working party of the Schools Council Music Committee.

Miles, M. \& Huberman, M. A. (1984). Qualitative Data Analysis. Beverly Hills: Sage.

National Curriculum Council (1992). Music Non-Statutory Guidance. York: National Curriculum Council.

Newby, P. (2010). Research Methods for Education. London: Pearson.

ONA, (2020). Music Secondary Key Stage 3: Curriculum plan 2020-21. Version 1.0. London: ONA.

Ofsted (2009). Making More of Music. London: Crown Copyright.

Ofsted (2013). Music in Schools: what hubs must do. London: Crown Copyright.

Ofsted (2013b). Music Survey Visits. London: Crown Copyright.

Ofsted (2019). School inspection handbook: Handbook for inspecting school in

England under section 5 of the education act 2005. London: Crown Copyright.

Paynter, J. (1982). Music in the Secondary School Curriculum: trends and developments in class music teaching. Cambridge: Cambridge University Press.

Paynter, J. (1992). Sound and Structure. Cambridge: Cambridge University Press.

Philpott, C. (2007). Musical Learning and Musical Development. Learning to Teach Music in the Secondary School: A Companion to School Experience. $2^{\text {nd }}$ edition. (Eds) Philpott, C. \& Spruce, G. Abingdon: Routledge.

Plummeridge, C. (2001). The place of music in the school curriculum. Learning to Teach Music in the Secondary School. $1^{\text {st }}$ edition. (Ed) Philpott, C. London: Routledge.

Plummeridge, C. (2002). What is music in the curriculum? Aspects of teaching secondary music: perspectives on practice. (Ed) Spruce, G. London:

RoutledgeFalmer.

Rudland, G. (2020). Developing the music curriculum: or what might be expected of a subject leader in a music deep dive. Presentation at Leicestershire School Music Service Music Educators Conference, 31/1/20.

Qualifications and Curriculum Authority (1999). Music: The National Curriculum for England. London: HMSO.

Qualifications and Curriculum Authority (2007). Music Programme of Study for Key Stage 3 and Attainment Target. London: HMSO.

Schools Council (1968). Enquiry One: Young School Leavers. London: HMSO. 
Sloboda, J. (1985). The Musical Mind, (1999 Edition, with corrections) Oxford: Oxford University Press.

Small, C. (1998). Musicking: The Meanings of Performing and Listening. Middletown: Wesleyan University Press.

Spielman, A. (2020). Speech given on 27/1/20 at Headteachers' Symposium on Creativity and Education about arts subject in schools and initial teacher education. Available at: https://www.gov.uk/government/speeches/amanda-spielman-speakingat-the-royal-opera-house Accessed on: 3/8/20.

Swanwick, K. (1979). A basis for music education. Windsor: NFER.

Swanwick, K. \& J. Tillman (1986). The sequence of musical development: a study of children's compositions. British Journal of Music Education 3 (3), pp. 305-309. Cambridge University Press.

Swanwick, K. (1999). Teaching Music Musically. London: Routledge.

Welch, G. (2005). We are musical. International Journal of Music Education. 23 (1), pp. 117-120. DOI: $10.1177 / 0255761405052404$.

Yin, R. K. (2009). Case Study Research: design and methods. Thousand Oaks: Sage. 